\title{
WHITMAN AND AMERICAN PERSONALISTIC PHILOSOPHY
}

\author{
BERNARD SCHMIDT
}

While Transcendentalism Clearly was the crowning product of the American Renaissance, its very prominence has created a critical myopia in the study of American philosophy of the mid-nineteenth century. For concurrent with the rise of Transcendentalism, another less prominent but extremely important philosophy was growing in New England: Personalism. This essay will demonstrate how American Personalism had its roots in Whitman's writing, and how it was basic to his thought.

A theistic form of idealism whose proponents consider the conscious, perceiving self the center of reality, Personalism maintains as its dominant concept that the intelligence of self explains theories, thoughts, and even God, who is usually considered a leader of active perceiving selves. Personalism therefore is a nonempirical philosophy in which the self obtains knowledge from a mighty power of reason, which is creative and can fashion reality from its own ideas. The self validates its perceptions from the physical world by subjecting them to its creative processes, but the physical world exists outside of the human mind and is not the product of a subjective idealism. In a cosmos where proud, potent selves possess powerful creative intelligence, each self earns from its peers respect for its abilities, and mutual respect creates the perfect intellectual and social milieu for democracy; tyranny becomes an aberration in a world of logical, productive selves. Americans have strongly influenced the evolution of Personalism, which holds that selves function in a concrete reality accessible to their perceptions and susceptible to their volitions. Whitman's democracy and optimism are generic to such a world.

Personalism has been almost entirely overlooked by American literary critics and historians. It is strange indeed that Transcendentalism could so totally subsume a philosophy that was then potent and is now almost unknown, but that is what has happened. Logical Positivism and the philosophy of the sciences displaced the various forms of idealism for a good part of the twentieth century, but before this occurred, the Boston school of Personalism was formed. ${ }^{1}$ Before most of the recognized Personalists wrote and spoke about their doctrines, Bronson Alcott, an acknowledged leader of the Transcendentalists, was recording notes in his journal about his discussions of Personalism with Emerson, who looked with some disfavor on Alcott's Personalistic ideas. How- 
ever, Alcott was a popularizer and not the inventor, if there is to be such a person, of American Personalism.

The American writer who first formally used the term "Personalism" was Walt Whitman. On Thursday evening, April 30, 1868, he wrote to his mother that "I received today another letter from old $\mathrm{Mr}$. Alcott-I sent him the Galaxy with Personalism - and he compliments me highly and speaks of Mr. Emerson too and his friendliness to me."2 The article referred to here is profound in its historical, if not its philosophical meaning, for in spite of its multiplicity of badly developed and underdeveloped points, Whitman's "Personalism" is the manifesto, the clarion call, of the American Personalist movement. The publication of the article was given scant attention, consisting of little more than a vituperative review in the Round Table, which according to Edward F. Grier "was apparently intended to put down Whitman once and for all." 3 "That the author of "Personalism" was more than momentarily serious about his new concept is demonstrated by the fact that he inserted sections of this article and other documents into one of his best prose declarations, Democratic Vistas. According to Floyd Stovall, lines 894 to 1275 of this work are filled with material taken from the older article, and certainly the reader may find frequent uses of the world "Personalism" elsewhere in Democratic Vistas, which was published in $1871 .{ }^{4}$

The Galaxy article on Personalism needs to be examined not only for its modest contribution to the history of American philosophy, but, of equal significance, for its usefulness in understanding Whitman's thought and interpreting his poetry. Whitman lacked the dialectical skill and logical powers to make major contributions to the building of a system of philosophy. He could provide some seminal ideas for what was to become the American Personalistic movement, but his thoughts would never have the sweep or development of a Borden Parker Bowne, Edgar Sheffield Brightman, or Albert Cornelius Knudson, and that may be why none of the major commentators on American Personalism give Whitman credit for anything beyond introducing the term into American philosophy.

Richard Chase's mention of Whitman's concern with the self as an independent unit which interacts with a complex world is accurate, but it must be pointed out that this cosmological view is Personalistic and may be traced back to Leibnizian monadology. In "The Monadology" Leibniz explains that simple entities are called "monads," and those which have strong powers of perception and memories are called "souls," a term which is here equated with "we" or selves. ${ }^{5}$ Although the various selves have independence, they are irretrievably related within the limits of God's universe, and the action of each effects all its neighbors, be they near or far. Chase was correct in observing the 
importance of Whitman's Personalism. From a study of Leibnizian monadology, it is safe to say that he was also correct in his observation that Whitman's " 'personalism' not only asserts the personal; it also, in some unspecified realm of being, 'fuses' men into 'solidarity'."' As observations in a microcosmic situation where no philosophic pattern need be found, Chase's notes on Whitmanesque Personalism are sound.

However, Whitman's world picture was part of the tradition of Personalism. His psychology is based on the existence of independent, highly complex selves. A democracy, the most perfect form of nation, is still an aggregate of individuals. When mankind is examined in any way or for any purpose, the unit of consciousness is the individual self. In this way Whitman avoids a total acceptance of Hegelian absolute idealism and its tendency to accept a single, universal mind. In his article "Personalism," Whitman makes it clear that when the mind dwells on the blessings of abstract entities-such as democracy, philosophy, or even the omnipresent spirit of God-it should "reduce the whole matter to the consideration of a single self, a man or woman," for the critical unit in Whitman's Personalism is the "single solitary soul."7 Real intelligence and consciousness are derived from the individual self. No political entity or philosophy can dominate the self, which can be an element in a religious universe only when it is free of the artifices and conformity imposed by organized religion.

Writing in 1908, Borden Parker Bowne showed just how central to Personalistic thought Whitman's psychology is. In "The Failure of Impersonalism," he claims that the self is more real than scientific abstractions; only the existence of the self is indubitable because it experiences a total awareness of its own consciousness, feelings, and reality. An abstraction just cannot do that. In attempting to establish or reflect the reality of the personality, scientific abstractions fail because deductions from "living experience" are our only true roads to knowledge. ${ }^{8}$ In words that Whitman could well have written in his Galaxy article, Bowne pleads that "the personal life" or "the selfconscious existence is the truly ultimate fact."9

Mary Whiton Calkins, who like the great Boston Personalists was a professor and philosopher and who taught at Wellesley College in eastern Massachusetts, also defines Personalism in a way that makes Whitman's article seem seminal. If Whitman had lived in the early twentieth century when Personalism had already been well defined by Bowne and Knudson, his article "Personalism" might well have included Mary Calkins's cogent description of the self, the element common to his philosophy. She builds her concept of the self by comparing it to its less substantial counterpart in Phenomenalism, and the contrast seems to validate the Personalistic construct. Although Personalism and Phenomenalism both hold that reality can only be perceived by an omnipotent 
consciousness, the Phenomenalist believes that consciousness is a concatenation of fleeting ideas. The Personalist believes that consciousness equals a self or person whose reality is made manifest by the fact that the person contains and controls ideas, which depend on his living consciousness for their existence. ${ }^{10}$ When in The Philosophy of Personalism Knudson defines Personalism as a form of idealism, "which finds in the conscious unity, identity, and free activity of personality the key to the nature of reality" (p. 87), he not only makes it clear that here is a philosophy centered around the intelligent potency of the self, he also continues the tradition in the United States that was initiated with Whitman's 1868 Galaxy article.

Whitman's division of reality into a "Me" and "Not Me," his trust in the creative activity of the democratic poet to work the "Me" into an improved world, and his trust in "the interior consciousness," are strong points in a Personalistic psychology. ${ }^{11}$ These are almost parallel to the four articles in Knudson's creed of Personalistic epistemology: "the dualism of thought and thing, or ideas and object, the creative activity of thought, the trustworthiness of reason, and the primacy of the practical reason." 12 The latter two items do not debase the value of emotion, but this construct is not central to the immediate problem of simple cognition. For the most profound processes of knowing, all Personalists affirm that the affective facets of experience have deep meaning in the quest for knowledge and universal values. ${ }^{13}$ However, there is a real world beyond the self and its affections, and Personalism is not normally a form of subjective idealism.

The "Me" and "Not Me" are fundamental to Whitman's epistemology. According to Marion Harris, the "Not Me" provides the materials for the "Me" to understand and is the second ingredient in the total of reality. The individual uses his senses to perceive nature or material existence, and then with the help of emotional insights he gains knowledge of the "internal spiritual world." 14 Harris does not go on to attempt to label or catalogue the poet's philosophy. If Whitman's "Me" and "Not Me" were the only critical doctrine in his cosmos, he would be a dualistic realist. The realist knows points of actual existence outside his own consciousness; he acknowledges "Not Me" entities that do exist. The idealist forces reality to become synonymous with his own consciousness or perceptions. Whitman is realistic in his "Me" and "Not Me" Weltanschauung and idealistic in his Hegelian declarations. These latter statements tend to absolute monism and therefore lead critics like Thomas L. Brasher to conclude that Whitman is an idealistic monist, as is exemplified in Section 8 of "Passage to India" when the persona's soul "continually moves to join the vast oneness of God.",15 For the true Personalist, extreme absolute, idealistic monism (of the type of Josiah Royce or Hegel) allows the absolute or God to steal too 
much independence and individuality from the basic selves. Although Personalism is primarily theistic, it considers the individual the prime organizer of his own perceptions, knowledge, and wisdom; the Personalist is never threatened by determinism.

Whitman's "Me" and "Not Me" dualistic world picture thus must be reconciled with his admiration for the monistic Hegelian absolute. In Specimen Days he pays homage to Hegel and claims that this philosopher provides the best explanation of how to link the "Me, the human identity of understanding, emotions, spirit," and the "Not $\mathrm{Me}$, the whole of the material objective universe and laws."16 The explanation, which Whitman sees in a simplistic form in Schelling but fully developed in Hegel, is that the force that links the "Me" to the "Not Me" is the "endless process of creative thought," which emanates from both individual selves and an amorphous, moral cause or "permanent morale"; this latter entity accepts all of the impulses, thoughts, and materials in the universe, which flow to it as "rivers" to an ocean. ${ }^{17}$ So the Hegelian absolute, the pride and the glory of absolute idealistic thought, is the conceptual glue which holds all of Whitman's "Me's" and "Not Me's" together. Leibnizian diversity and its establishment of various selves must be reconciled with Hegelian absolute idealism.

It is tempting not only to the reader but to Whitman himself to give his absolute ideal realm a Platonic omnipotent reality in his metaphysical thought. In his article "Personalism," Whitman observes that selfhood is religious and possesses the concept of the infinite. Each self realizes that:

Finally, the theme, great as it is, of the Personality of mortal life is most important with reference to the immortal, the Unknown, the Spiritual, the only permanent real, which, as the ocean waits for and receives the rivers, waits for us each and all. ${ }^{18}$

As in Specimen Days, the selves are compared to rivers which flow to the ocean of an infinite absolute vastness, which is certainly a God-like entity. All of this seems to make Whitman's monistic absolute idealism official, but "Song of Myself," which is probably Whitman's most definitive statement of his occasionally contradictory beliefs, breathes forth an atmosphere, almost a dogma, that makes each individual self the center of the universe. When Whitman says that each person, each you, must take perceptions from "all sides and filter them from your self," 19 his epistemology may tend to associationalism-the idea that knowledge is empirical and originates in the senses, and that mental images are formed through a physical transmission of sensations.

In Section 3 of "Song of Myself," Whitman tells the reader that "Clear and sweet is my soul, and clear and sweet is all that is not my soul. / Lack one lacks both, and the unseen is proved by the seen, / Till that becomes unseen and receives proof in its turn" of the other's reality 
(52-54). The prime mover of this image is the soul or self which accepts the validity of the "not my soul" as being equal in importance to itself in the total harmony of the universe. "Lack one lacks both," and the subjective and objective worlds through mutual, reciprocal perceptions and interactions contribute to the other's reality and realization. In simple terms, the Platonic or Hegelian idealist longs to have his soul enter a world of ideal forms or form. His goal is to flee the environs of flesh and find the realm of spiritual beauty. For Whitman, the things of earth - the sweat, grass, prairie-dogs, breasts - are holy in a manner that is just not so for the idealistic monist.

In this cosmological structure, the self is not a "river" or lesser entity that flows into an "ocean" or greater entity. Whitman's writings must be taken as parts of a whole and not always coherent ideological structure, but there are key themes that help the reader comprehend his mind-set. An organizing device around which is built the philosophy of Personalism, the self unites Whitman's dualistic and monistic worlds. Thus, one of the few titles which Whitman's mysterious cosmos can definitively be given is Personalistic.

Whitman did not often bother to distinguish a less sophisticated entity or self from a more complex, sagacious entity or person, as did some other Personalists, but this actually serves to add unity and impact to his idea of selfhood. This selfhood, so evident in poems like "Song of Myself" or even the short "One's-Self I Sing," has definite Personalistic characteristics.

When Whitman says “One's-Self I Sing, a simple separate person,/ Yet utter the word Democratic, the word En-Masse" (1-2), he is translating into poetic form his concept of the "Me" and "Not Me." As it is explained in Specimen Days, the "Me" is "human identity" or self, the subjective world, and the "Not Me" is the "whole of the material" world. ${ }^{20}$ This establishes a certain modern realism in Whitman's epistemology; there is a real, independently existent world that needs to be perceived. This does not deprive the Whitmanesque poet of his power of "creative activity of thought" $-\mathrm{a}$ phrase coined by Knudson to describe the important ability of the mind to formulate its own reality. ${ }^{21}$ The poet in Whitman's world can attempt to force the "Not Me" to suit the will of "Me." In the Greek and Whitmanesque sense of the poet as maker or creator, the writer can "sing" into existence the perfect political reality of democracy, "breathing into it a new breath of life" and imparting to it permanence heretofore unavailable. ${ }^{22}$ In this way, a national literature is created from "archetypal poems"; "the priest departs, the divine literatus comes." 23 Personalistic thinkers accept the democratic society as the natural place for the self to prosper and grow. Emmanuel Mounier, the French Personalist, makes much of the need for a flexible environment for the personality to develop and sees any 
form of tyranny as wrong. Like Whitman, Mounier tends to equate nondemocratic government with bad government.

George Howison, who was a part of the Concord School of Philosophy during the evening of the "Golden Day" of Transcendentalism, was one of the opponents of absolute idealism; he felt that Hegelianism nullified personality, morality, and individual choice and ultimately led to determinism. ${ }^{24}$ However, in his credo for Personalism, which he calls Personal Idealism, he describes a cosmos that resonates with ideas similar to Whitman's in "Song of Myself." In both worlds pluralism deters a repressive monism because the individuality of all selves, Godly or not, is established by the fact that they perceive and think, a process essential to Personalism. A cosmic logic unites a "World of Spirits" and God into an "unmoved one that moves all things." 25 Howison stresses the fact that God is not a solitary dictator, but a part of a world of selves that finds meaning and unity in its common moral impulse and latent power. Freedom, not determinism, is the welcome by-product of the willing interaction of the selves and God. When Knudson discusses the Personalistic view of the pluralistic and monistic aspects of reality, he suggests a monistic pluralism rather than Howison's pluralistic monism. In his urge to justify his theism, Knudson claims that there must be "a monism that transcends the dualism of thought and thing without destroying it." ${ }^{26}$ Knudson's system is a monistic pluralism because in it the multitude of selves is strongly guided by a theistic force. However, the juxtaposition of Howison's and Knudson's Personalistic epistemological systems clarifies the basic tension between Whitman's Hegelian monistic cosmos and his pluralistic one, peopled by the supermen of democracy.

It may well be that this tension will allow of no resolution, but the attempt may at least suggest a different way to analyze Whitman's writing and thought. The well-developed superman theme in "Song of Myself" may be explained as an outgrowth of Whitman's pluralistic tendencies. The individual selves and their wonderful abilities to create through thought are a given in his cosmos. A self that is a maker or creator cannot be accused of classical hubris. It is quite capable of conquering space and time and may logically claim, "I heard what was said of the universe, / Heard it and heard it of several thousand years" (1024-1025). This self comfortably and calmly studies the characteristics and capabilities of the mightiest gods of many different religions:

Taking myself the exact dimensions of Jehovah,

Lithographing Kronos, Zeus his son, and Hercules his grandson,

Buying drafts of Osiris, Isis, Belus, Brahma, Buddha,

In my portfolio placing Manito loose, Allah on a leaf, the crucifix engraved,

With Odin and the hideous-faced Mexitli and every idol and image,

Taking them all for what they are worth and not a cent more. . . .

(1028-1032) 
For the Whitmanesque self, there is no true arrogance in these statements, and the persona of the poem consistently explains "the supernatural of no account, myself waiting my time to be one of the supremes" (1049). In fact, in Section 48, Whitman explicitly states that "nothing, not God, is greater to one than one's self is" (1271). Man's self-consciousness organizes the world with his perceptions at the center, and this is Personalistic. ${ }^{27}$

Another product or symptom of Whitman's Personalism is his view of nature. For Whitman, "Nature consists not only in itself, objectively, but at least just as much in its subjective reflection from the person, spirit, age, looking at it." 28 Nature, then, is important only as it emanates from the individual; otherwise it is part of the "Not Me." That is why "the rule and demesne of poetry will always be not the exterior"; "not Nature but Man."29 Howison says, "Man the spirit, man the real mind, is not the offspring of Nature, but rather Nature is in a great sense the offspring of this true Human Nature," also making the point that nature is, at least to some extent, the reflection of the perceiver's self. ${ }^{30}$

In Democratic Vistas Whitman describes three stages probably representing a Hegelian scheme for thesis, antithesis, and synthesis, which will lead to the establishment of his land of supermen or super Americans, his "Religious Democracy." 31 In the first stage the United States was planned and brought to life. The second stage saw material prosperity, and the third, in which priestcraft gives way to poetcraft, is yet to be achieved. In this last stage "the great literatus will be known among the rest by his cheerful simplicity, his adherence to natural standards, his limitless faith in God." 32 The second stage sees the triumph of science and materialism, not evils in themselves, but instruments to be used in the struggle to build a world that fits the high standards of Personalistic values. Once again Whitman's Personalism may be read in the words of the Personalistic philosopher Howison, who asks that "men of science keep the method of science within the limits of science." "33 Science and religion need not be adversaries. However, science must explore only physical reality; it may conquer profane realms, but the sacred and the theological are not appropriate for its investigations.

The Personalistic thinkers were often regarded as dreamers by the philosophers of science. In fact, they did tend to construct idealistic views of reality. However, thinkers like Whitman and Bowne maintained a healthy respect for science, without allowing that discipline to rule their thoughts. These men always sang the "Song of Myself" or other selves in their cosmological constructs. For this reason they were immune to the kind of error made by B.F. Skinner who, by mistaking 
a methodology for a philosophy, ruthlessly seeks to destroy humanistic, mentalist constructs and to reduce man to an automaton moved only by determinants in his environment. There is a peculiar irony in this situation because the naiveté shown by the scientist in accepting a part of reality as the whole is the kind of error that he would very likely attribute to the philosopher. The insistence that the human self is the real birthplace of knowledge and authority, which is assumed in the evolutionary theory of the three stages, is the reason that Whitman and other Personalists are interested in Christ as a model for human behavior rather than as a deity; the religious creeds of other men mislead rather than lead the soul to the correct paths. The theistic democracy of the third stage of Whitman's evolutionary process is too spiritually pure to tolerate the machinations of partisan religious groups.

All of the famous American Personalists of the late nineteenth or early twentieth century, from Bowne to Ralph Tyler Flewelling, give either minimal or no credit to Whitman as a precursor to their thoughts, so it is understandable that later critics should be unaware of his contribution. The Personalistic system builders refer to honored philosophers like Leibniz and Kant, whom they claim as contributors to Personalism. When Edgar Sheffield Brightman says that "In the United States Walt Whitman stressed democratic aspects of Personalism," he is giving Whitman as much recognition as do any of the historians of Personalism; ${ }^{34}$ they have neither the time nor the inclination to recognize the conceptual meanderings of an earthy American poet who was not lionized by the academic community of his day.

During the "Golden Day" of American history, New England Transcendentalism - a point of confluence for Hindu, German, French, and American idealism - was the dominant American philosophy. Although it was distinctly syncretic, it continued the intellectual stream that was to reach its high tide in Pragmatism, showed that at least an informal American philosophy could gain world fame, and, of even greater significance, was thoroughly and totally American.

Personalism is not only inextricably linked to Transcendentalism through the Personalistic writing of Bronson Alcott, but it is pervasive in the literary mind of the United States. Men such as Francis Wayland Parker and John Dewey brought forth the Pragmatic educational theories, which demand that the selfhood of the child be the center of the educational process. Therefore, through the vehicle of Personalistic philosophy, future studies may show new relationships between such rarely compared works as Dewey's Democracy and Education and Whitman's Democratic Vistas. Personalistic emphasis on the self as the creator or organizer of reality also suggests a link with Existentialism. Wherever the Personalistic path leads, it should not be forgotten that there was a 


\title{
distinct philosophical school that formally began with Whitman's article "Personalism."
}

\author{
Saint Augustine's College
}

\section{NOTES}

1 Borden Parker Bowne was the first and most significant leader of the Boston school of Personalism. The other important proponent of American Personalism in the nineteenth century was George Holmes Howison, but he founded neither a system nor a school. Teaching at the University of California for the greater part of his career, he was isolated from the New England theocratic intellectualism in which Bowne's thoughts flourished and lived on (see Joseph L. Blau, Men and Movements in American Philosophy [Englewood Cliffs, NJ: Prentice Hall; 1952], p. 189). Bowne reacted against the positivism of his day by rigorously affirming the self as the omniscient perceiver of reality. To demand that the self be taken as an entity whose existence needed to be scientifically verified was naive. Common sense showed that the self was the primary agent of verification. That conscious experience created the only true reality was the basic idea of Bowne's "Transcendental Empiricism" (Blau, p. 201).

Bowne taught his doctrines at Boston University from 1876 until his death in 1910. His pluralistic idealism and Personalistic theism were carried forward by three prominent students; two, like Bowne, also taught at Boston University. Albert Knudson published The Philosophy of Personalism (New York: Abingdon Press, 1927), and this comprehensive study is the definitive history of Personalism. In cogent books, articles, and lectures, Edgar Sheffield Brightman successfully continued Bowne's attempt to systemize and explain Personalism. Ralph Tyler Flewelling, like Howison, took the movement west. Flewelling founded the journal, The Personalist, at the University of Southern California. (See John H. Lavely, "Personalism," The Encyclopedia of Philosophy, ed. Paul Edwards [New York: Macmillan, 1967], 6:109.)

2 Edwin Haviland Miller, ed., The Correspondence (New York: New York University Press, 1961), 2:30-31.

3 Edward F. Grier, "Walt Whitman, The Galaxy, and Democratic Vistas," American Literature 23 (November 1951), 347.

4 Floyd Stovall, ed., "Democratic Vistas," Prose Works (New York: New York University Press, 1964), 2:390-391. Hereafter abbreviated $P W$.

5 Gottfried Wilhelm Leibniz, "The Monadology," The Rationalists, trans. George Montgomery (New York: Dolphin Books, 1960), 458.

6 Chase describes Whitman's Personalism as a synonym for "identity," but he does not note that Whitman's key word initiates a philosophical system, thereby leaving what he calls Whitman's "new urgency" and "new clarity" only partially explained. See Richard Chase, "The Theory of America," Walt Whitman Reconsidered (New York: William Sloane Associates, 1955), 159-163.

7 Walt Whitman, "Personalism," The Galaxy 5 (1868), 541.

8 Borden Parker Bowne, "The Failure of Impersonalism," The Development of American Philosophy, ed. Walter Muelder, et al. (Boston: Houghton Mifflin, 1960), 284.

9 Bowne, 284. 
10 Mary Whiton Calkins, The Persistent Problems of Philosophy (New York: Macmillan, 1923), 406-409.

11 Whitman "Personalism," 544.

12 Knudson, 99.

13 Knudson, 155.

14 Marion Harris, "Nature and Materialism: Fundamentals in Whitman's Epistemology," Walt Whitman Review 9 (December 1963), 88.

15 Thomas L. Brasher, “A Modest Protest against Viewing Whitman as Pantheist and Reincarnationist," Walt Whitman Review 13 (September 1967), 93.

$16 P W, 1: 258$.

$17 P W, 1: 259$.

18 Whitman, "Personalism," 547.

19 Harold W. Blodgett and Scully Bradley, eds., Leaves of Grass: Comprehensive Reader's Edition (New York: W.W. Norton, 1973), 30. All quotations from Whitman's poems are from this source.

$20 P W, 1: 258$.

21 Knudson, 96.

$22 P W, 2: 365$.

$23 \cdot P W, 2: 365$.

24 George Holmes Howison, George Holmes Howison: Philosopher and Teacher, ed. John Buckham and George Stratton (Berkeley: University of California Press, 1934), 126.

25 Howison, 130.

26 Knudson, 153.

27 James T.F. Tanner says that Whitman's superman once again places man at the center of the universe from which he was driven by science: he describes the poet's belief in a superman as a "personal humanism." So Tanner touches on a Personalistic note in Whitman's thoughts, but does not study Whitman as a Personalist. See James T.F. Tanner, "The Superman in Leaves of Grass," Walt Whitman Review 11 (December 1965), 96.

$28 P W, 2: 485$.

$29 P W, 2: 485$.

30 Howison, 185.

$31 P W, 2: 410$.

$32 P W, 2: 414$.

33 Howison, 189.

34 Edgar Sheffield Brightman, "Personalism," A History of Philosophical Systems, ed. Vergilius Ferm (New York: Philosophical Library, 1950), 343. 